\title{
Hydrodynamics as a Major Factor Controlling the Occurrence of Green Macroalgal Blooms in a Eutrophic Estuary: A Case Study on the Influence of Precipitation and River Management
}

\author{
I. Martins ${ }^{a}$, M. Â. Pardal ${ }^{a}$, A. I. Lillebø ${ }^{a}$, M. R. Flindt ${ }^{b}$ and J. C. Marques ${ }^{a}$ \\ ${ }^{a}$ IMAR-Institute of Marine Research, clo Department of Zoology, University of Coimbra, 3004-517 Coimbra, \\ Portugal \\ ${ }^{b}$ Biological Institute, Southern Danish University Odense, Campusvej 55, DK-5230 Odense M, Denmark
}

Received 24 April 2000 and accepted in revised form 30 August 2000

Data on the variation of physicochemical parameters, biomass and growth of green macroalgae (mostly Enteromorpha) collected between January 1993 and January 1997 in the Mondego Estuary (western coast of Portugal) was analysed with the aim to identify the factors that control opportunistic macroalgal abundance in the system.

The annual biomass of Enteromorpha spp. is strongly dependent on the amount of fresh water that enters the system during winter and spring. In turn, the input of fresh water is regulated by precipitation and by river management practices. The optimization of the rice crops from the upstream valley depends on their water level, which determines the number of days and hours per day during which sluice gates remain open in winter and spring. River flow has significant impacts on salinity, N:P ratios, current velocities and light extinction coefficients within the system. The interaction of all these factors controls macroalgal growth and biomass loss processes.

In winters and springs during which sluice gates are often closed due to water deficiency of the rice fields (dry winter and spring or dry winter followed by rainy spring), little fresh water enters the system and consequently, salinity remains high, N:P ratios around 20, light penetration increases, and current velocities fall. These conditions facilitate macroalgal fixation, enhance their growth and spring blooms occur. On the contrary, during winters and springs when fresh water is in excess of rice fields' needs (rainy winters and springs), sluice gates remain open for long periods of time. High input of fresh water to the system causes salinity and light penetration to decrease, while N:P ratios and current velocities increase. These conditions contribute both to reduced Enteromorpha growth and higher loss of macroalgal biomass from the system to the ocean.

The present work shows that the inter-annual variation of macroalgal biomass in the Mondego Estuary is controlled by hydrodynamics, which in turn depends on precipitation and on river management, according with the water needs of the upstream rice crop.

(C) 2001 Academic Press

Keywords: eutrophication; Enteromorpha; hydrodynamics; river management; precipitation; rice crop

\section{Introduction}

Nowadays macroalgae constitute the dominant primary producers of most eutrophic temperate coastal systems (Geertz-Hansen et al., 1993; Kolbe et al., 1995; Sfriso, 1995; Peckol \& Rivers, 1996; Hernández et al., 1997; Valiela et al., 1997; Flindt et al., 1997a). Due to the complex and important links that macroalgae establish with other components within the system (e.g. seagrasses-Herman et al., 1996; McClelland \& Valiela, 1998; Lapointe et al., 1994; Short et al., 1995; Masini et al., 1995; Koch \& Beer, 1996; macrofauna-Raffaelli et al., 1991; Lillebø et al., 1999; Pardal et al., 2000; wading birds-Múrias et al., 1996, 1997; Lopes et al., 2000; sediment characteristics and composition-Neira \& Rackemann, 1996; nutrient cycles-Viaroli et al., 1992, 1993, 1996; Valiela et al., 1997), it becomes essential to know which variables control macroalgal abundance and regulate their biomass. Although, these factors will differ from system to system, their identification at each coastal area will contribute to a deeper knowledge of coastal eutrophication and, possibly deal with this environmental problem by helping to find suitable mitigation measures.

The aim of this work was to identify the main factors controlling opportunistic macroalgal growth in the south arm of the Mondego Estuary and to understand how these factors regulate the yearly standing crop of macroalgal populations. 


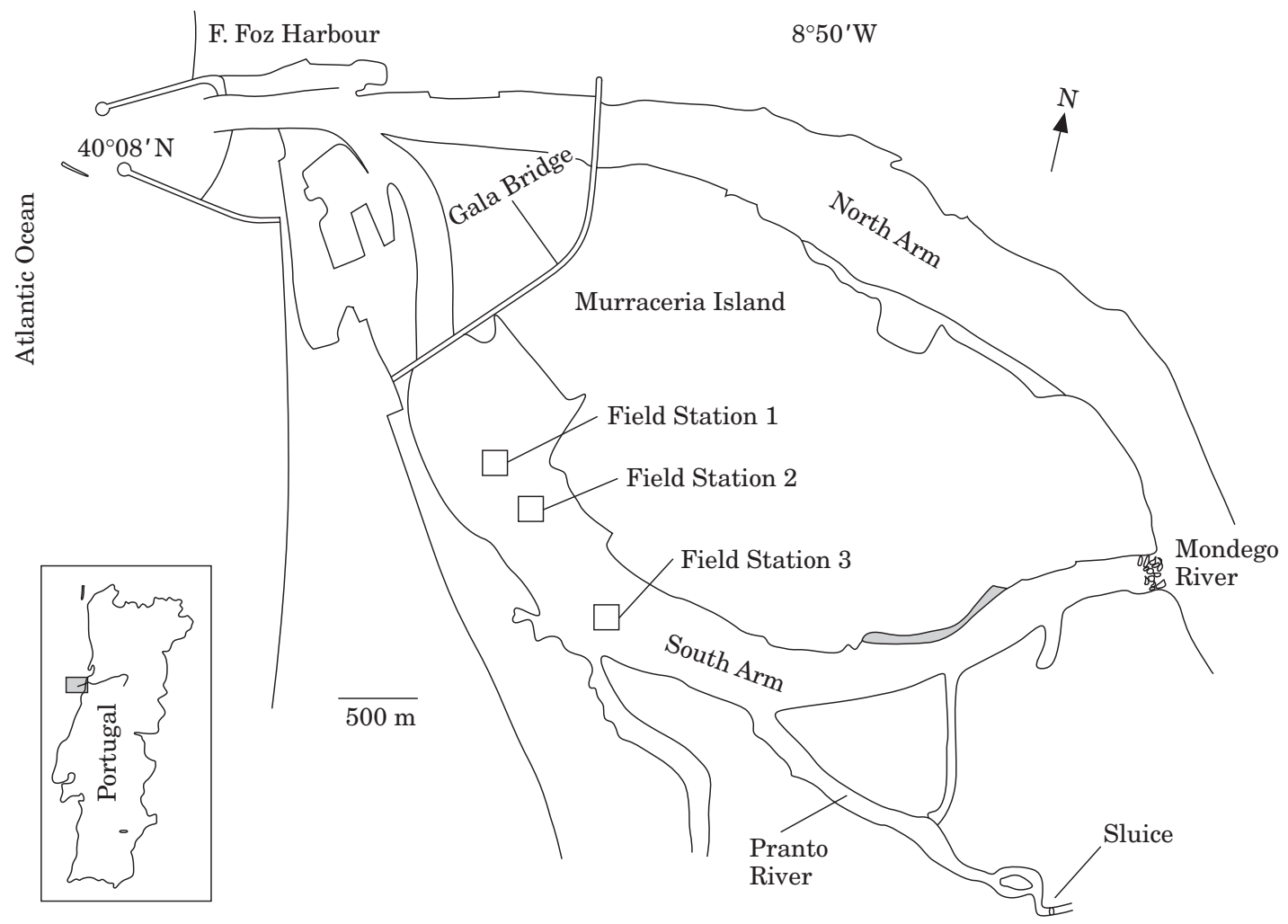

FIgURE 1. The Mondego Estuary with indication of the field stations along the south arm.

\section{The Mondego Estuarine system and data available}

\section{Study site}

The Mondego Estuary, located on the Atlantic coast of Portugal $\left(40^{\circ} 08 \mathrm{~N}, 8^{\circ} 50 \mathrm{~W}\right)$, is about $7 \mathrm{~km}$ long, with an area of approximately 1072 ha of wetland habitats. The estuary consists of two different arms, north and south, separated by an alluvium-formed island (Murraceira Island) (Figure 1). The north arm is deeper (4-8 $\mathrm{m}$ during high tide, tidal range 1-3 $\mathrm{m}$ ) and constitutes the main navigation channel and the location of the Figueira da Foz commercial harbour. Due to dredging activities in the north arm, related with harbour facilities, and to the fact that the south arm is almost silted up in its upper part, the river discharge flows predominantly through the north arm. As a consequence of the combined effects of fresh water discharge and tidal penetration, the north arm has higher daily salinity changes, and the bottom sediments consist mainly of medium to coarse sand (Marques et al., 1993a). The south arm is shallower (2-4 $\mathrm{m}$ during high tide, tidal range $1-3 \mathrm{~m}$ ), and due to siltation in its upstream section the water circulation is mostly dependent on the tides and the fresh water input from the Pranto River (Marques et al., 1993b; Flindt et al., 1997a). The discharge from the Pranto River is controlled by a sluice (Flindt et al., 1997a; Pardal et al., 2000), and is regulated according to the water needs in rice fields from the Pranto Valley. Due to fertilizers used in the rice crops (Anastácio et al., 1999; Lillebø et al., 1999; Pardal et al., 2000; Martins, 2000), the freshwater discharge proceeding from the Pranto into the south arm also represents an important inorganic nutrient (mainly nitrogen) input to the system (Flindt et al., 1997a). For a more detailed characterization of the system see also Pardal (1998), Marques et al. (1997, 1999).

\section{Reference and monitoring studies}

Previous work on the ecology of the Mondego Estuary was carried out throughout the 1980s (Marques \& Nogueira, 1991; Marques et al., 1993a, b). A major conclusion regarding structure and biodiversity of the macrobenthic communities was that the north arm constituted an impoverished sub-system in comparison with the south arm. This was attributed to a higher instability of the north arm sediments, mainly caused by dredging activities (Marques et al., 1993b). The richest area in the system with regard to macrofaunal abundance and biodiversity was found to be the 
Zostera noltii meadows located downstream of the south arm (Marques et al., 1993a). As a whole, the south arm was considered less affected by human activities. It was nevertheless pointed out that, due to its natural features (shallowness, hydrodynamics) and to the discharge of inorganic nutrients from the Pranto River, it would also be more vulnerable to environmental stress (Marques et al., 1993a, b). During the 1990 s, eutrophication became a problem in the south arm and macroalgal blooms, especially of Enteromorpha spp., occurred repeatedly (Marques et al., 1997; Flindt et al., 1997a; Pardal, 1998; Lillebø et al., 1999; Martins, 2000). The most abundant Enteromorpha species in the system are E. intestinalis (L.) Link and E. compressa (L.) Greville, which are found attached to small stones, empty shells, wood sticks or polychete tubes. Although Enteromorpha individuals are present throughout the year, macroalgal growing season starts in late winter and their maximal biomass usually occurs in spring. Summer is characterized by low macroalgal biomass and a second but smaller biomass peak may occur in early autumn (Pardal, 1998; Martins, 2000).

During the last decade the south arm of the Mondego Estuary has been almost continuously monitored with respect to: (a) environmental factors, namely inorganic nutrient concentrations in the water column (Marques et al., 1997; Flindt et al., 1997a; Lillebø et al., 1999; Martins, 2000; Pardal et al. 2000); (b) biomass variation and productivity of benthic primary producers (Martins, 2000; Pardal et al., 2000); (c) population dynamics and production of macrofaunal key species (Marques et al., 1994; Lillebø et al., 1999; Pardal et al., 2000); (d) seasonal and inter-annual variation of wading birds (Múrias et al., 1996, 1997); (e) impacts of macroalgae blooms on macrofaunal communities and waders (Múrias et al., 1996; Martins et al., 1997; Lillebø et al., 1999; Lopes et al., 2000; Pardal et al., 2000). This paper deals with the relationships between external abiotic variables and the growth and biomass of Enteromorpha spp. in the south arm of the estuary.

From January 1993 to December 1994, samples of macrophytes, macroalgae and associated macroinvertebrates were taken every 2 weeks and then monthly until September 1995 (except January 1995) at three places (stations 1,2 and 3) (Figure 1) during low water tide (Pardal et al., 2000). The choice of these places was related with the observation of a macroalgal coverage gradient in the south arm, increasing from downstream to upstream. Each time at each site, 6 to 10 cores (with a $143 \mathrm{~cm}^{2}$ section) were taken from a depth of $15 \mathrm{~cm}$. Each core was placed in a separate plastic bag and sieved within an hour of sampling by washing it in estuarine water through a $500 \mu \mathrm{m}$ mesh sieve. The residue (sediment, macrophytes, algae and animals) was placed into plastic bottles and preserved with $4 \%$ formalin in estuarine water. In the laboratory, all material was separated and processed (Pardal, 1998; Lillebø et al., 1999; Pardal et al., 2000). In the case of green macroalgae, individuals were separated by genus, dried (for $48 \mathrm{~h}$ at $60{ }^{\circ} \mathrm{C}$ ) and ash free dry weight (AFDW) was assessed after combustion of samples for $8 \mathrm{~h}$ at $450^{\circ} \mathrm{C}$. Simultaneously, temperature $\left({ }^{\circ} \mathrm{C}\right)$, salinity, dissolved oxygen ( $\mathrm{mg}^{-1}$ and \%) and $\mathrm{pH}$ data were measured in situ and water samples (approximately $250 \mathrm{ml}$ ) were collected for estimating dissolved inorganic nutrients $\left(\mathrm{PO}_{4}-\mathrm{P}, \mathrm{NO}_{3}-\mathrm{N}\right.$, $\mathrm{NO}_{2}-\mathrm{N}$ and $\mathrm{NH}_{4}-\mathrm{N}$ ). In the laboratory, water samples were filtered and analysed following Greenberg et al. (1992) procedures for orthophospate and $\mathrm{N}$-compounds.

From January 1996 to January 1997, monthly growth experiments with Enteromorpha spp. were conducted in the estuary at station 3 where, in favourable years macroalgal accumulation tends to be higher. Macroalgae were kept inside semi-cylindrical plexiglass devices surrounded laterally and on the bottom by $500 \mu \mathrm{m}$ calibrated net. This type of device allowed light penetration and water circulation inside and prevented, at the same time, grazers from entering (Martins, 2000). In each experiment, 20 healthy Enteromorpha individuals were collected in the field, washed carefully with estuarine water and weighed (initial wet weight) after the excess of water had been removed. Then, macroalgae were taken to the field inside the plexiglass devices, which were fixed by ropes to wooden sticks buried in the sediment. Groups of five replicates were removed from the field after 5, 10, 15 and 20 days and weighed to final wet weight. Monthly growth rates were estimated as the slopes of fitted regressions, after ln transformation of data considering an exponential growth model (Sokal \& Rohlf, 1996). At the same time in stations 1 and 3, physicochemical parameters were measured and water samples collected, following the procedure previously described.

From June 1993 to May 1994, information on the daily number of hours during which sluice gates were opened was provided by the rice farmers. In the same period, during some of the days when the sluice gates were opened, current velocities were measured at the inlet (immediately after the sluice) and the outlet of the south arm (immediately after the Gala Bridge) (Figure 1) at different depths. Additionally, River Pranto discharge were calculated taking in consideration current velocities and the 


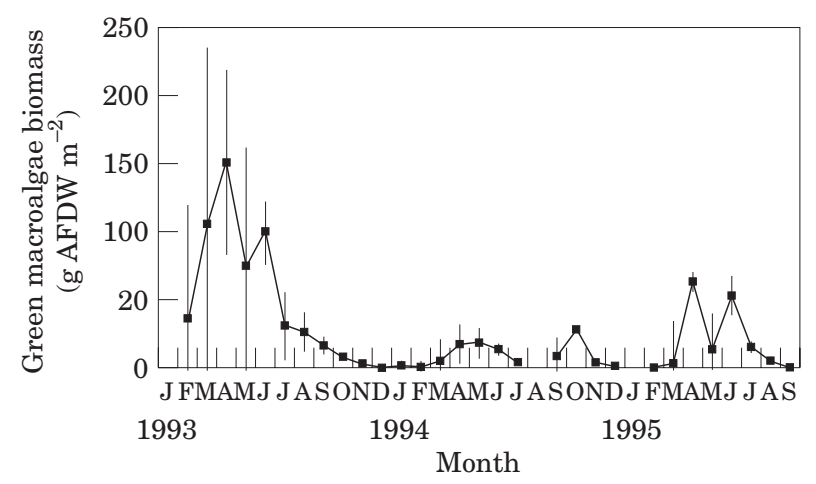

FIGURE 2. Average green macroalgal biomass ( $\mathrm{g} \mathrm{AFDW} \mathrm{m}{ }^{-2}$ ) \pm standard error (SE) at the three field stations from 1993 to 1995 . Enteromorpha spp. constituted $85 \%$ of total green macroalgal biomass.

section of the river. Data on tidal amplitude were collected from a tide table provided by the Portuguese Harbour Institute.

During 1997, four seasonal $24 \mathrm{~h}$ cycles (one per season) were carried out at station 3 and hourly measurements of physicochemical parameters were performed, including PFD (photon flux density, $\mu$ moles photons $\mathrm{m}^{-2} \mathrm{~s}^{-1}$ ) which was measured at the surface and at the maximum depth. Using these data the light extinction coefficient was calculated through Beer's law:

$$
I_{z}=I_{0} \times e^{-k z}
$$

where $I_{z}$ is light intensity (light units) at depth $z$ (depth units), $I_{0}$ is light intensity at the surface (light units) and $k$ is the light extinction coefficient (depth units $^{-1}$ ), solved to the form:

$$
k=\frac{\ln I_{0}-\ln I_{\mathrm{z}}}{z}
$$

Data on precipitation were obtained from the Geophysics Institute of the University of Coimbra and concern precipitation values at the City of Coimbra (located about $40 \mathrm{~km}$ east of the Mondego Estuary).

\section{Results}

\section{Green macroalgal biomass and growth}

Throughout the entire period of macroalgal sampling (1993-1995), Enteromorpha spp. represented more than $85 \%$ of the total biomass of green macroalgae and important inter-annual variations were detected (Figure 2). In 1993, the average green macroalgal biomass in the south arm was about

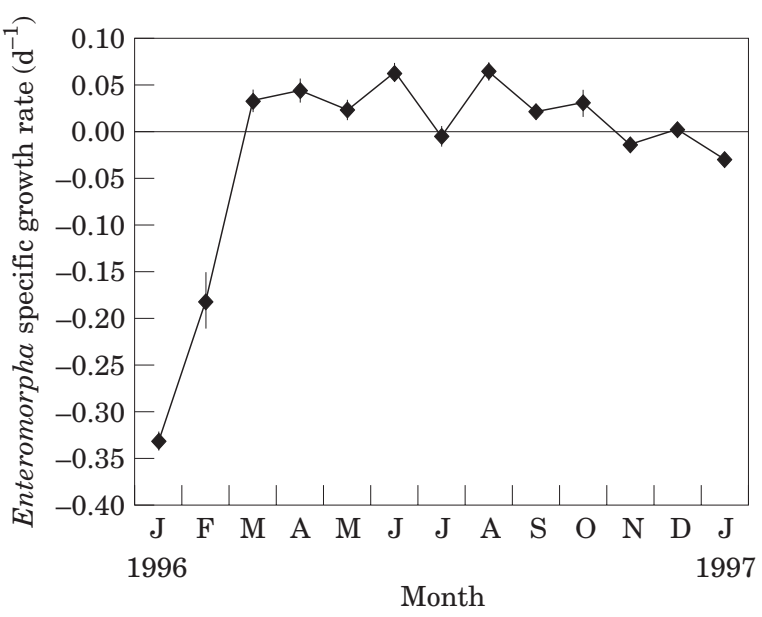

FIGURE 3. Monthly Enteromorpha spp. growth rates $\left(\mathrm{d}^{-1}\right) \pm$ standard error (SE) $(N=25)$ estimated from January 1996 to January 1997 at station 3 .

$149 \mathrm{~g} \mathrm{AFDW} \mathrm{m}^{-2}$, while in 1994, it attained only $26 \mathrm{~g} \mathrm{AFDW} \mathrm{m}^{-2}$. In spring 1993, the maximum biomass of macroalgae ( $409 \mathrm{~g} \mathrm{AFDW} \mathrm{m}^{-2}$ ) was detected in station 3, while in 1994, the maximum value $\left(49 \mathrm{~g} \mathrm{AFDW} \mathrm{m}^{-2}\right.$ ) was registered in station 2 . In the spring of 1995 (March-June), the average macroalgal biomass ( $33 \mathrm{~g} \mathrm{AFDW} \mathrm{m}^{-2}$ ) was intermediate between spring (March-June) average biomass in 1993 and in 1994 (Figure 2) and similar values were detected in station 2 and 3 .

During 1996, no significant spring Enteromorpha bloom was observed in the south arm of the Mondego Estuary (personal observation) and Enteromorpha growth rates ranged from negative values, during winter and autumn, to a maximum of $6 \%$ day $^{-1}$ in June and August (Figure 3).

\section{$\mathrm{NO}_{2}-\mathrm{N}, \mathrm{NO}_{3}-\mathrm{N}, \mathrm{NH}_{4}-\mathrm{N}, \mathrm{PO}_{4}-\mathrm{P}$ and $\mathrm{N}: \mathrm{P}$ variation}

Dissolved inorganic nutrients are monthly averages from station 1 and 3, the two places where water samples were almost continuously collected from January 1993 to January 1997.

Throughout the study period, the variation of $\mathrm{NO}_{2}-\mathrm{N}, \mathrm{NO}_{3}-\mathrm{N}$ in the water column followed a similar yearly pattern, usually with higher concentrations in autumn and winter, and lower concentrations in spring and summer (Figure 4). However, the relationship between $\mathrm{NO}_{2}-\mathrm{N}+\mathrm{NO}_{3}-\mathrm{N}$ and precipitation is not always direct, as could be seen in spring 1993 (Figure 4). In spite of the significant precipitation in April and May, the amount of nitrite and nitrate did not increase in the system. On the contrary, the Pranto River discharge, which expresses 


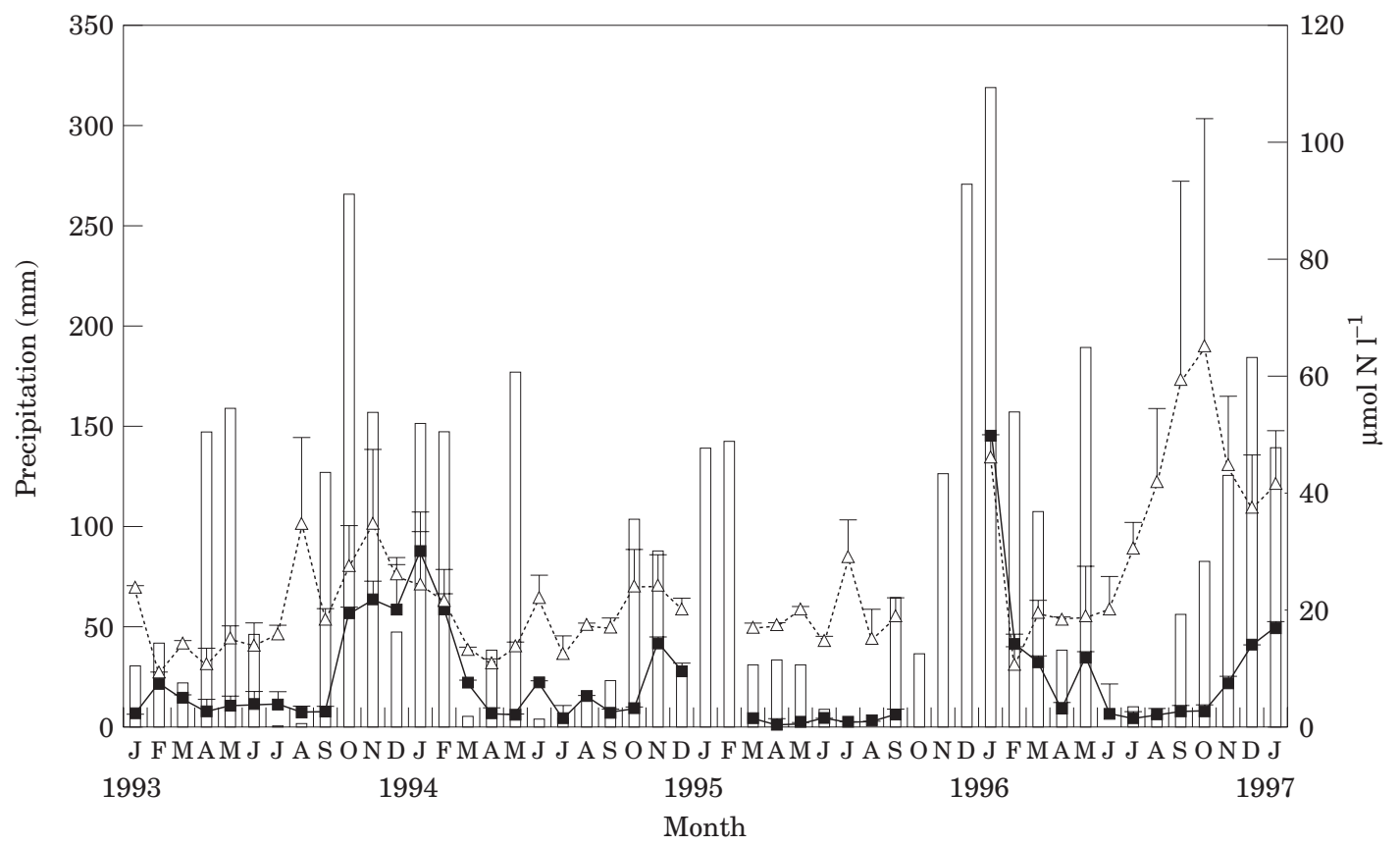

FIGURE 4. Variation of precipitation (mm), nitrite + nitrate and ammonium $\left(\mu \mathrm{mol} \mathrm{N} 1^{-1}\right)+1 \mathrm{SE}$ in stations 1 and 3 between January 1993 and January 1997. Bars: precipitation; squares: $\mathrm{NO}_{2}-\mathrm{N}+\mathrm{NO}_{3}-\mathrm{N}$; triangles: $\mathrm{NH}_{4}-\mathrm{N}$.

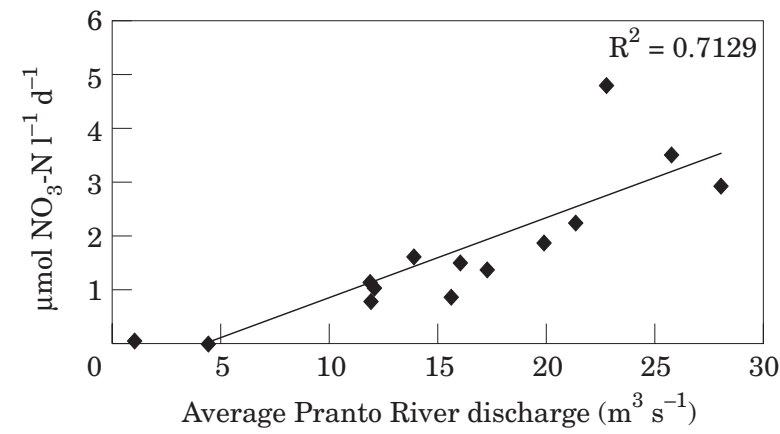

FIGURE 5. Relationship between Pranto River discharge $\left(\mathrm{m}^{3} \mathrm{~s}^{-1}\right)$ and nitrate concentration of the water $(\mu \mathrm{mol}$ $\mathrm{NO}_{3}-\mathrm{N}^{-1}$ ) at the inlet, immediately after sluice gates $\left(N=14, \mathrm{R}^{2}=0 \cdot 71\right)$.

directly the amount of fresh water entering the system, is highly correlated with $\mathrm{NO}_{3}-\mathrm{N}$ concentration at the inlet (immediately after the sluice) (Figure 5).

$\mathrm{NH}_{4}-\mathrm{N}$ variation did not show any clear relationship with precipitation and values tend to increase from summer until autumn and early winter (Figure 4). $\mathrm{NH}_{4}-\mathrm{N}$ variation was highly and positively correlated with total inorganic nitrogen (Figure 6), which reflects the important contribution of ammonium to the total inorganic nitrogen concentration in the south arm of the estuary.

Throughout the study period, the highest concentrations of $\mathrm{PO}_{4}-\mathrm{P}$ occurred mostly during summer

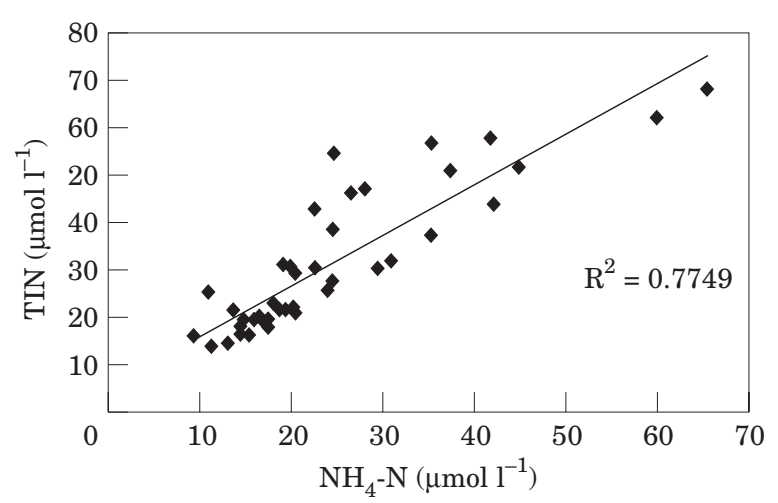

FIGURE 6. Relationship between ammonium and total inorganic nitrogen concentrations $\left(\mu \mathrm{mol} \mathrm{N} 1^{-1}\right)$ in the south arm of Mondego Estuary $\left(N=43, \mathrm{R}^{2}=0 \cdot 77\right)$.

(Figure 7). As suggested by Figure 8, in the system the efflux of phosphorus from sediments to the water column is related with temperature.

Although N:P ratios usually increased with precipitation (Figure 9), reflecting the increase in $\mathrm{NO}_{2}-\mathrm{N}$ and $\mathrm{NO}_{3}-\mathrm{N}$ in the system, the relationship between the two parameters is not direct (Figure 10). This is in agreement with the fact that, sometimes the occurrence of precipitation is not translated in fresh water input to the system (as in spring 1993) and the increase in $\mathrm{NH}_{4}-\mathrm{N}$, the major contributor to TIN in the system, is not dependent on precipitation. Additionally, the inverse relationship between $\mathrm{N}: \mathrm{P}$ 


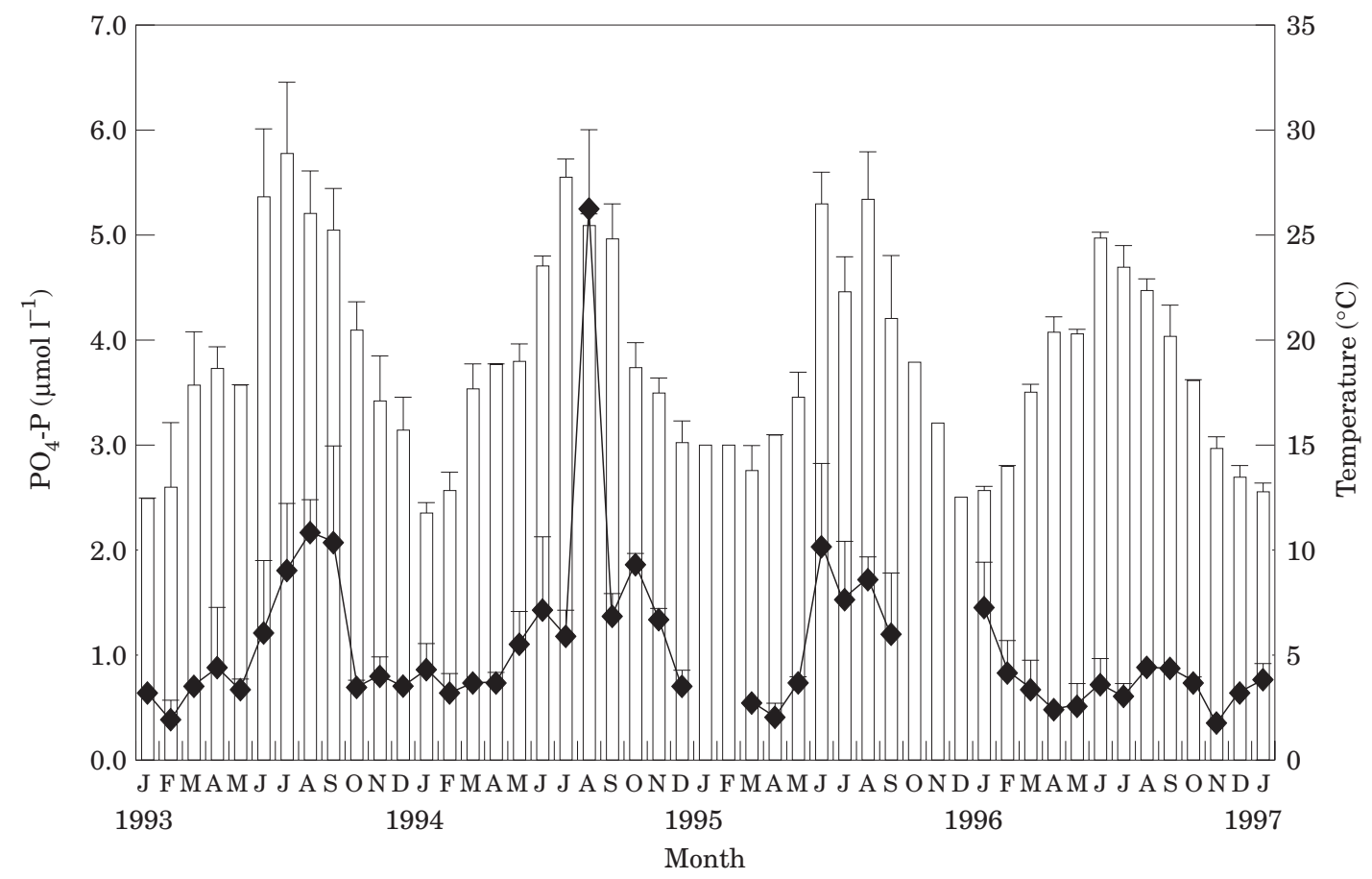

FIGURE 7. Variation of temperature $\left({ }^{\circ} \mathrm{C}\right)$ and orthophosphate $\left(\mu \mathrm{mol} \mathrm{PO}_{4}-\mathrm{P} 1^{-1}\right)+1 \mathrm{SE}$ in stations 1 and 3 between January 1993 and January 1997. Bars: temperature; diamonds: $\mathrm{PO}_{4}-\mathrm{P}$.

ratios and salinity (Figure 11) suggests that whenever salinity decreases, $\mathrm{N}: \mathrm{P}$ ratios increase. The decrease of salinity depends on the amount of fresh water input from the river as explained next.

\section{Salinity variation}

During periods with significant precipitation like October-December 1993, January-February 1994, January-February 1995 and the end of 1995 and the beginning of 1996, salinity dropped to less than 20 , reaching sometimes values equal or lower than 5

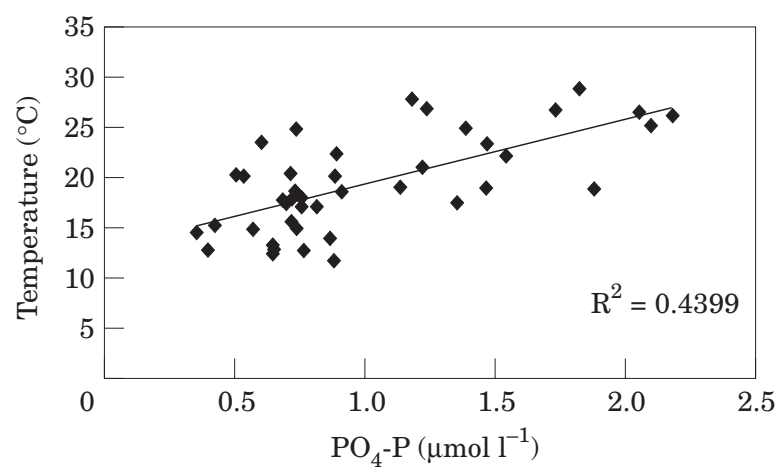

FIGURE 8. Relationship between orthophosphate ( $\mu \mathrm{mol}$ $\mathrm{PO}_{4}-\mathrm{P}^{-1}$ ) and temperature $\left({ }^{\circ} \mathrm{C}\right)$ in the south arm of the Mondego estuary $\left(N=43, \mathrm{R}^{2}=0 \cdot 44\right)$.
(Figure 12). However, the dependency of salinity on precipitation is not direct, for instance, in April-May 1993 and in October-November 1994, the increased precipitation was not followed by a decrease of salinity (Figure 12). This is related with river management practices. If the upstream rice fields have a waterdeficit, the sluice gates are kept closed even if it is raining. Thus, considering data from the whole period of study, the variation of salinity is not clearly related with precipitation [Figure 13(a)]. On the contrary, in a wet year such as 1996, the correlation between salinity and precipitation is high and inverse [Figure 13(b)] because in this situation, sluice gates are often opened to avoid rice fields being flooded.

Sluice management, Pranto River discharge and current velocities

The variation of the number of hours per day during which the sluice gates remained opened from October 1993 to May 1994, and the daily precipitation variation in the same period, suggest that sometimes there is a time lag between the occurrence of precipitation and the opening of the sluice gates and that, when precipitation stops, sluice gates remains open for a longer period (Figure 14). From October to December 1993, the average number of hours during which the sluice gates remained opened was 


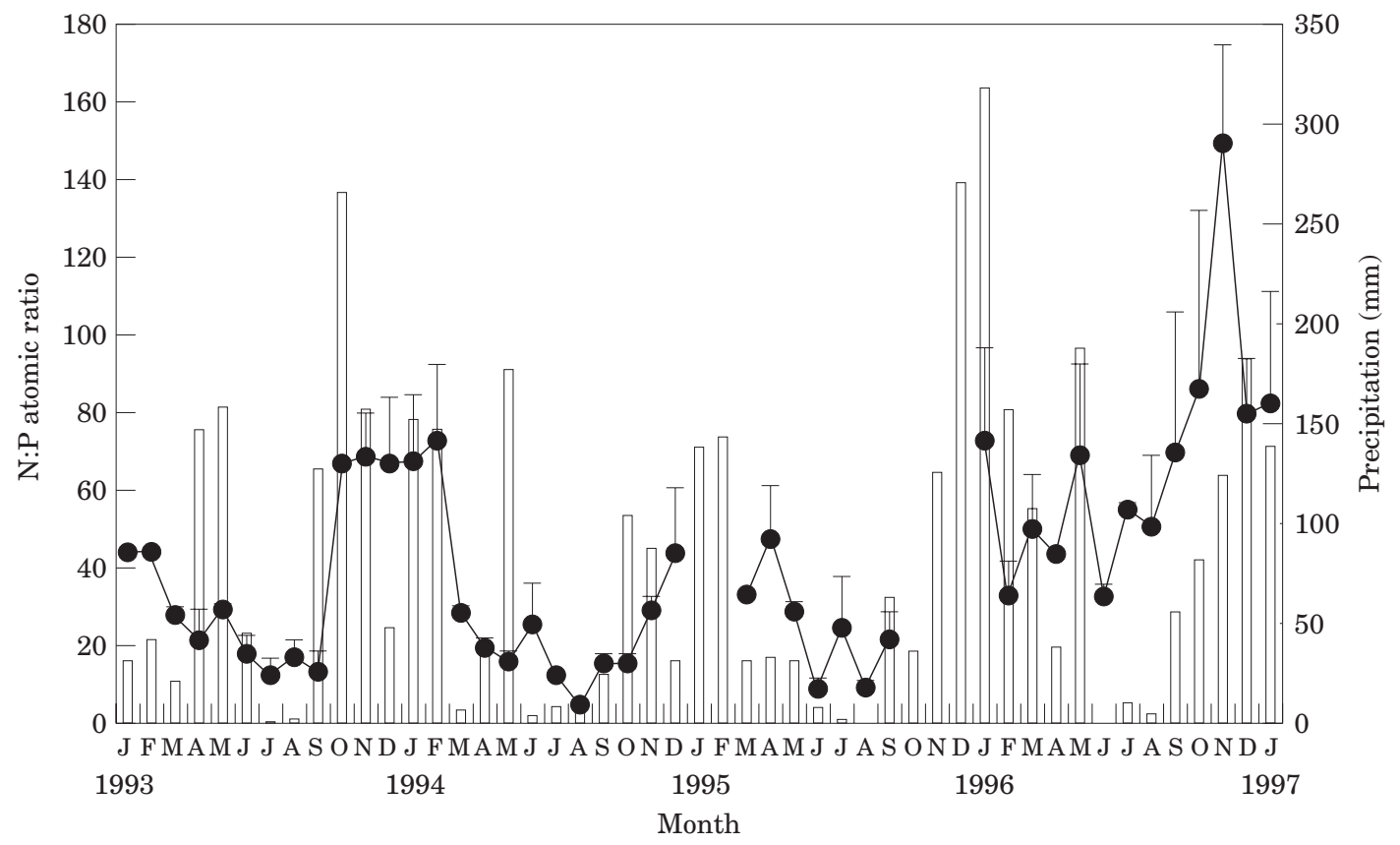

FIGURE 9. Variation of precipitation ( $\mathrm{mm}$ ) and N:P atomic ratio of the water+1 SE in stations 1 and 3 between January 1993 and January 1997. Bars: precipitation; circles: N:P.

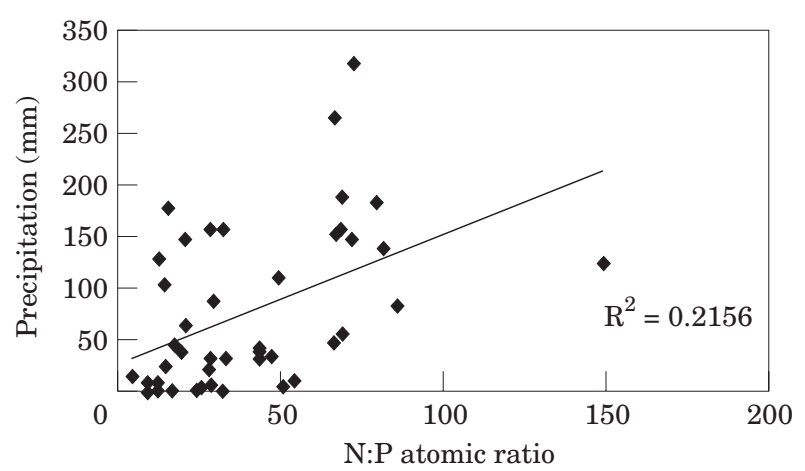

FIGURE 10. Relationship between N:P atomic ratio and precipitation $(\mathrm{mm})$ in the south arm of Mondego Estuary $\left(N=44, \mathrm{R}^{2}=0 \cdot 22\right)$.

correlated with average daily precipitation, but that situation changed during 1994. In March 1994, the amount of precipitation was very low and yet the sluice gates opened almost every day, with an average of $6 \mathrm{~h}$ per day. In April 1994, a dry month, the sluice was almost always closed, even during the precipitation in late April. The significant precipitation during middle and late May 1994 was, however, followed by intensive sluice gate opening. The average number of hours per day during which the sluice gates remained opened was negatively correlated with salinity (Figure 15). Additionally, although sluice gates might be kept open in periods of low precipitation (like March 1994), the Pranto River discharge differs

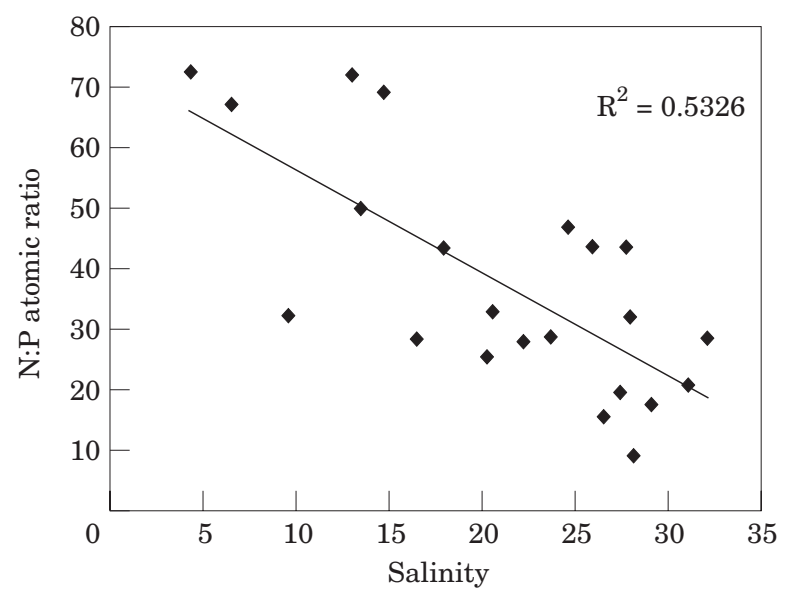

FIGURE 11. Relationship between salinity and N:P atomic ratio in the south arm of Mondego Estuary between January and June (winter/spring) 1993-1996 $\left(N=22, \mathrm{R}^{2}=0 \cdot 53\right)$.

between periods of low and periods of high precipitation (Figure 16). According to our results, there is a direct relationship between maximal current velocities and tidal amplitude, and for the same tidal amplitude, current velocities are higher when sluice gates are opened (Figure 17).

\section{Light extinction coefficient variation}

Average values of light extinction coefficient were estimated during the seasonal $24 \mathrm{~h}$ cycles, which did 


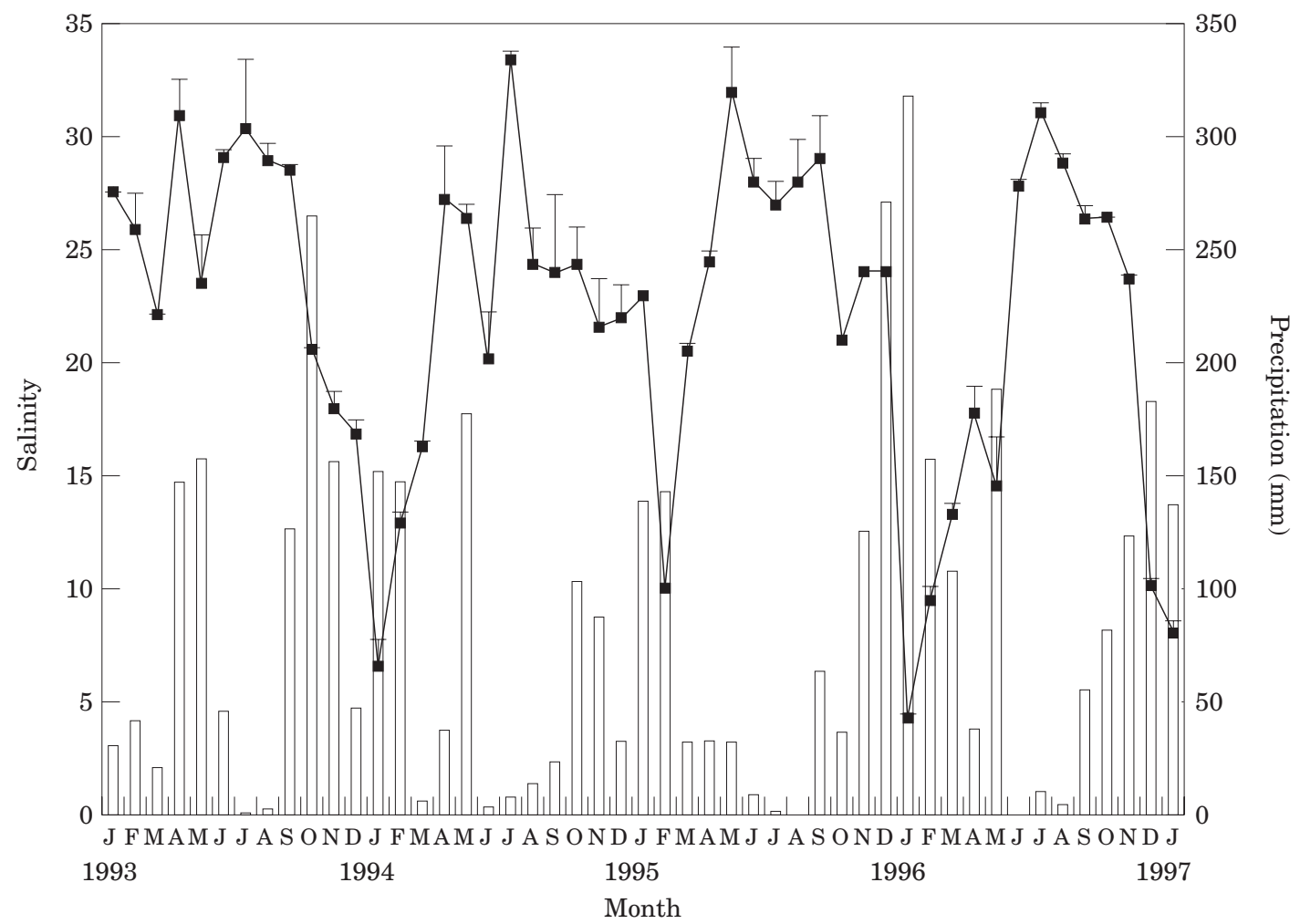

FIGURE 12. Variation of precipitation (mm) and salinity+1 SE in stations 1 and 3 between January 1993 and January 1997. Bars: precipitation; squares: salinity.

not correspond to typical season days. For example, the winter cycle was carried out in a dry day preceded by a dry period $(0 \mathrm{~mm}=$ cumulative precipitation for the period of 1-week before sampling) with high PFD (Martins, 2000). The importance of these results remains in the fact that, the average light extinction coefficient estimated in autumn (cumulative precipitation $=75.8 \mathrm{~mm}$ ) was about $5.59 \mathrm{~m}^{-1}$, while winter, spring and summer averages (cumulative precipitation $=0,40 \cdot 8$ and $0 \mathrm{~mm}$, respectively) were 1.55 , 1.99 and $1.92 \mathrm{~m}^{-1}$, respectively (Figure 18 ).

\section{Green macroalgal biomass and salinity}

The relationship between green macroalgal biomass and salinity is not direct. In summer when salinity is higher (>25), macroalgal biomass is usually very low (Figure 19). However, in winter-spring (FebruaryJune) with higher salinity, green macroalgal biomass is also higher, as suggested by the exponential increase of macroalgal biomass with salinity (Figure 20).

\section{Discussion}

The results suggest that, in the south arm of the Mondego Estuary, the growth and production of
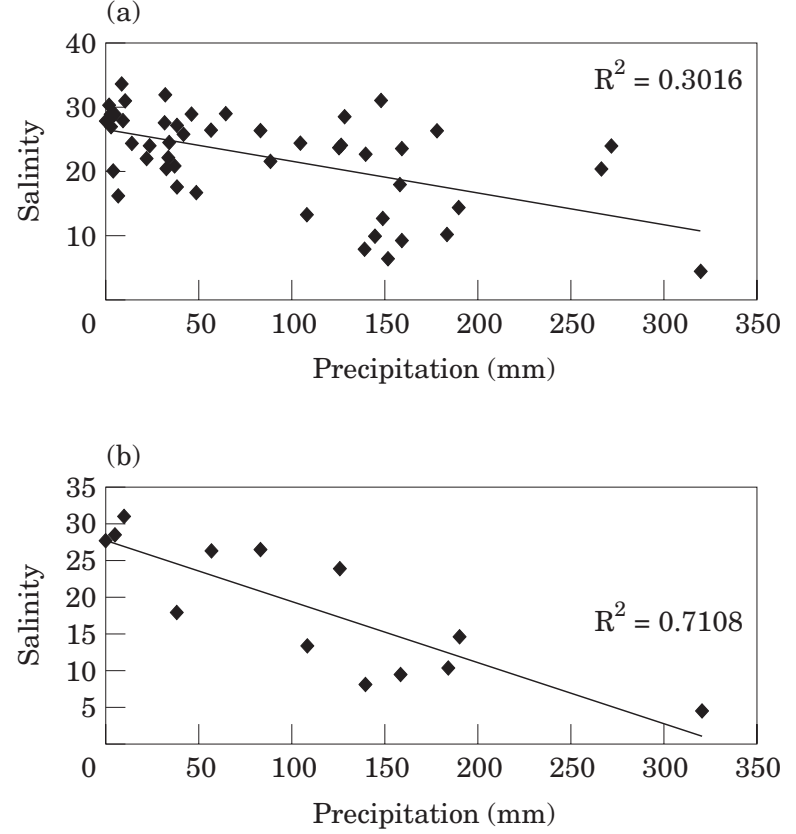

FIGURE 13. Relationship between precipitation ( $\mathrm{mm}$ ) and salinity in the south arm of the Mondego Estuary, (a) throughout the entire study period $\left(N=49, \mathrm{R}^{2}=0 \cdot 30\right)$, (b) only in 1996, the most rainy year of the study period $\left(N=13, \mathrm{R}^{2}=0 \cdot 71\right)$. 

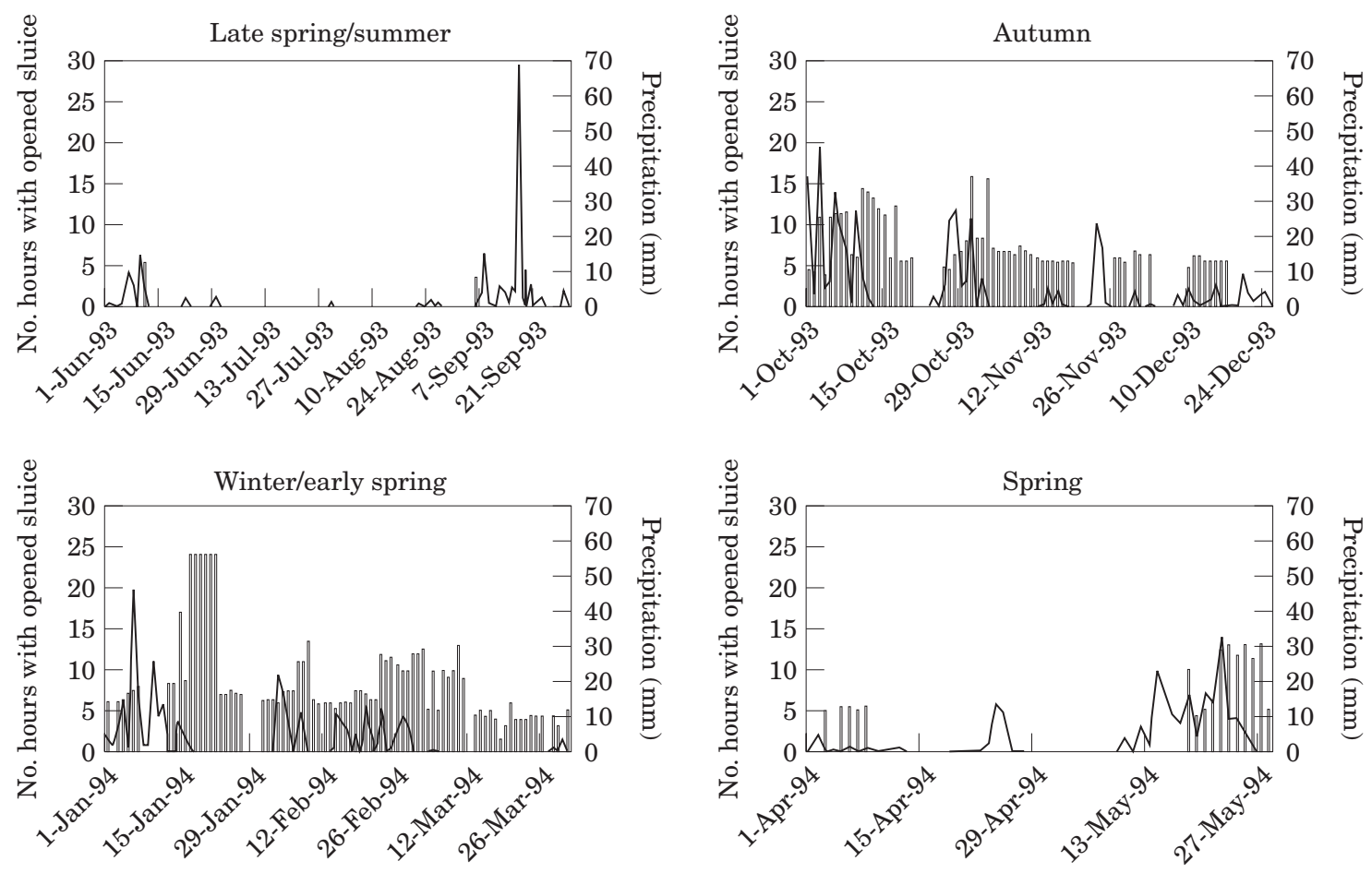

FIGURE 14. Number of hours during which sluice gates were opened (column) and precipitation (line) during late spring/summer (June-September 1993), autumn (October-December 1993), winter/early spring (January-March 1994) and spring (April-May 1994).

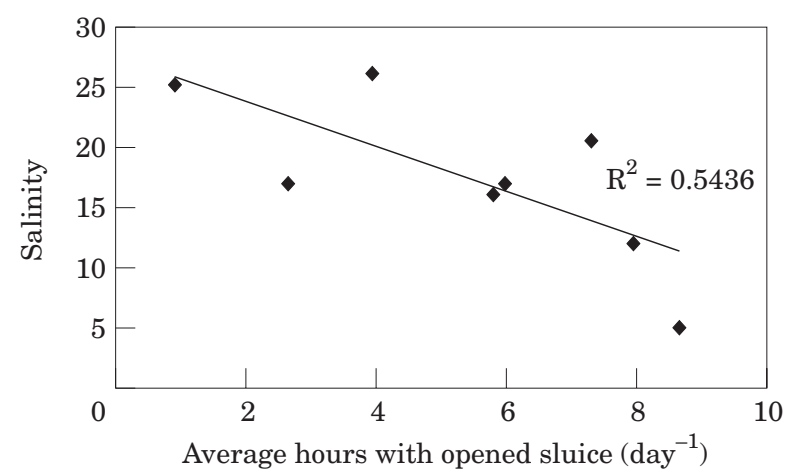

FIGURE 15. Relationship between the average number of hours during which sluice gates were opened $\left(\right.$ day $^{-1}$ ) and salinity in the south arm of the Mondego Estuary.

green macroalgae (especially Enteromorpha) depends on the amount of fresh water entering the system in late winter and spring. In turn, the amount of fresh water entering the system varies according with both precipitation and river management practices. In years with dry winters and springs, the upstream rice fields get water deficient and rice farmers keep the sluice gates closed. The same situation occurs in a rainy spring preceded by a dry winter, such as 1993 . In spite of the spring rain, sluice gates were mostly closed, in

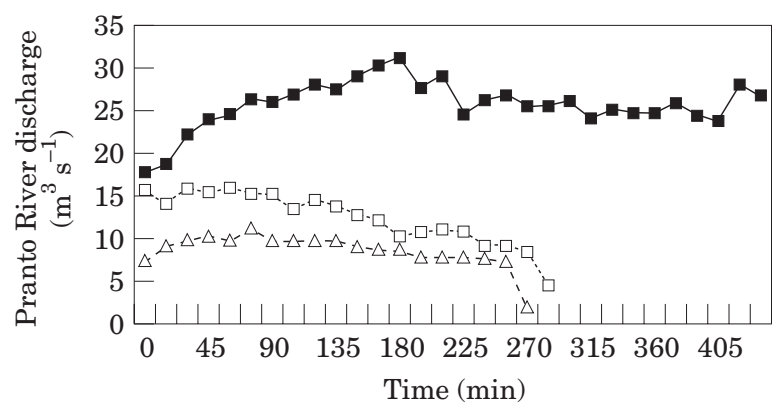

FIGURE 16. Pranto River discharge $\left(\mathrm{m}^{3} \mathrm{~s}^{-1}\right)$ in three different days in 1994: 18 January-high precipitation, 11 March-no precipitation, 26 May-high precipitation after a dry period. Closed squares: winter-high precipitation; open squares: spring - precipitation after a dry period; open triangles: spring — no precipitation.

order to re-establish the necessary water level in rice fields. From March to September, the Pranto valley rice fields must keep a constant level of water to optimize the annual rice crop (Anastácio et al., 1999). Thus, in rainy winters and springs, the sluice gates remain open for long periods and several hours per day, allowing the excess of fresh water to flow from the valley into the south arm.

The quantity of fresh water flowing in the south arm will then determine the variation of other abiotic 


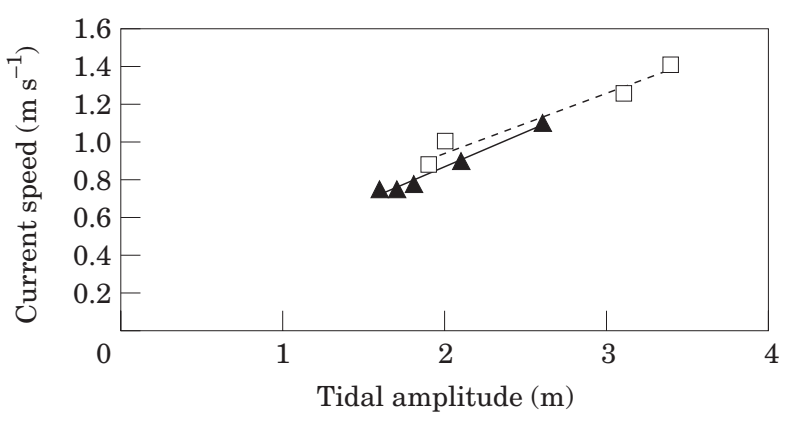

FIgURE 17. Variation of current velocity $\left(\mathrm{m} \mathrm{s}^{-1}\right)$ with tidal amplitude $(\mathrm{m})$ with opened sluice gates $\left(N=4, \mathrm{R}^{2}=0.96\right)$ and with the closed sluice gates $\left(N=5, \mathrm{R}^{2}=0 \cdot 98\right)$. Squares: opened sluice; triangles: closed sluice.

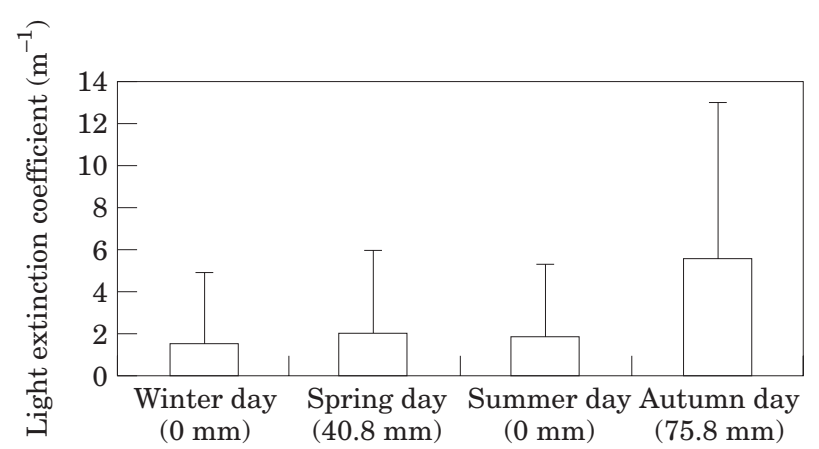

FIGURE 18. Average light extinction coefficients $\left(\mathrm{m}^{-1}\right)$ of the water column estimated in the days when seasonal cycles were carried out. Bars are $95 \%$ confidence interval for means and $\mathrm{N}$ (winter) $=6, \mathrm{~N}$ (spring) $=5, \mathrm{~N}$ (summer) $=9$ and $\mathrm{N}$ (autumn) $=6$. The numbers in brackets represent the cumulative precipitation of 1 -week before measurements.

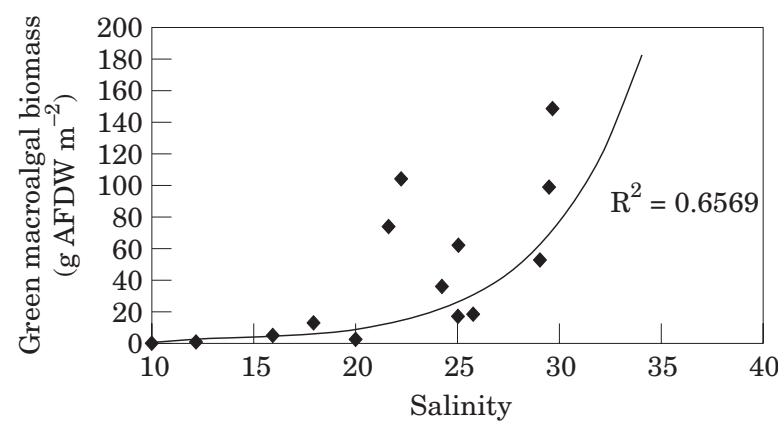

FIGURE 20. Relationship between salinity and green macroalgal biomass (g AFDW $\mathrm{m}^{-2}$ ) in the Mondego Estuary between January and June (winter/spring) of 1993-1995 $\left(N=16, \mathrm{R}^{2}=0 \cdot 66\right)$.

variables. Salinity is negatively correlated with the number of hours during which sluice gates remains open, thus salinity remains high $(\geq 20)$ when the river flow is low such as in winter/spring of 1993 and 1995 (except January 1995) and falls to less than 15, whenever river flow increases significantly. Sometimes, average salinity may reach extremely low values $(\leq 5)$, such as in January 1994 and January 1996. The input of fresh water to the system also contributes to $\mathrm{N}$-enrichment of the water column, as suggested by the relationship between Pranto River discharge and $\mathrm{NO}_{3}-\mathrm{N}$ concentration. The increase in $\mathrm{NO}_{3}-\mathrm{N}$ and $\mathrm{NO}_{2}-\mathrm{N}$ together $\mathrm{NH}_{4}-\mathrm{N}$ concentration, which constitutes the main contributor to TIN in the system, contributes to the occurrence of very high $\mathrm{N}: \mathrm{P}$ ratios

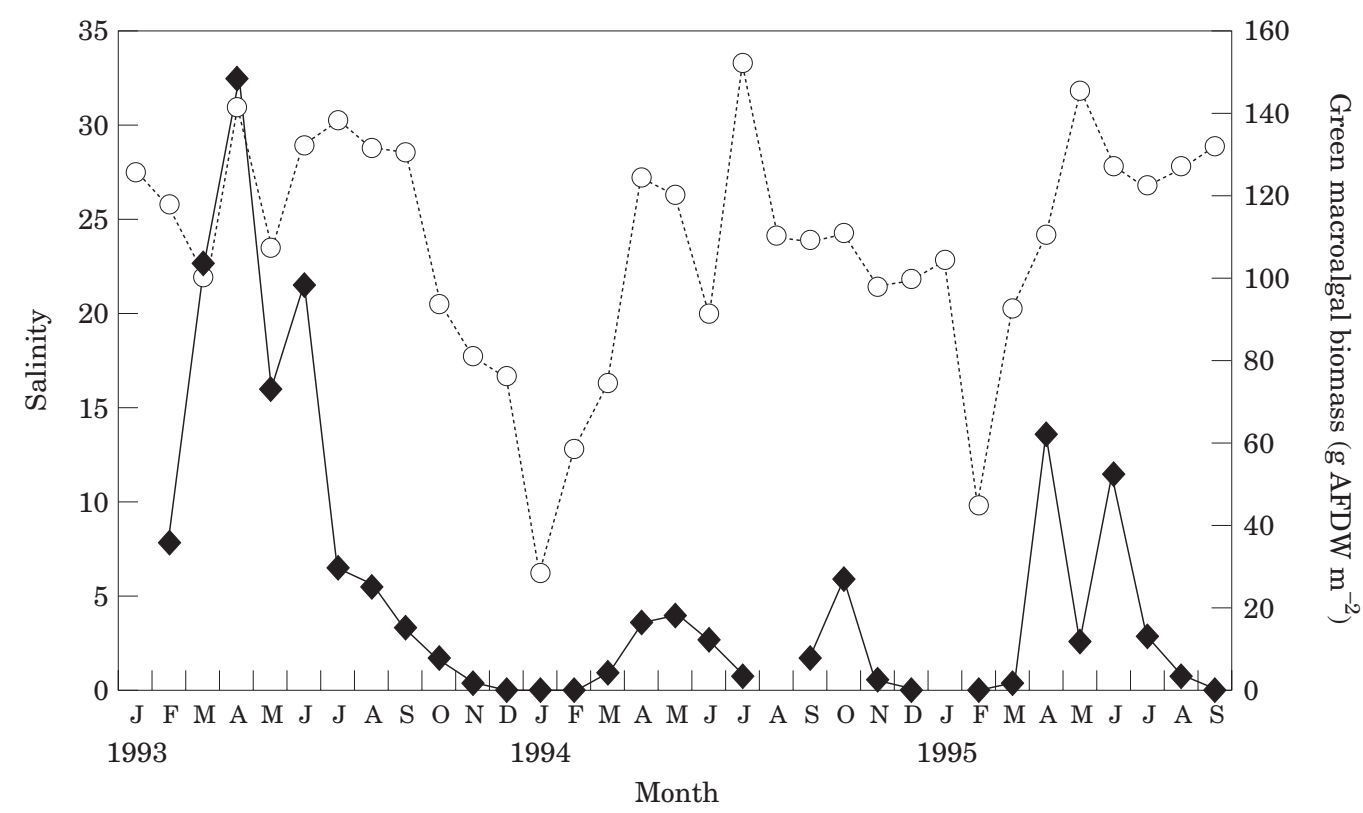

FIGURE 19. Variation of green macroalgal biomass (g AFDW $\mathrm{m}^{-2}$ ) and salinity from January 1993 to September 1995 in the south arm of the Mondego Estuary. Circles: salinity; diamonds: biomass. 
in the water column during periods of significant river flow. This is also suggested by the tendency to increased $\mathrm{N}: \mathrm{P}$ ratios with decreased salinity (Figure 11). In a shallow and mesotidal environment, such as the south arm of the Mondego Estuary, water-flow velocity depend both on tidal amplitude and on the input of fresh water and, naturally that for the same tidal amplitude, water-flow velocity is higher whenever more fresh water is entering the system, as suggested by Figure 17. Additionally, light extinction coefficients will be higher whenever water flow rises due to significant re-suspension of sediments.

It is the variation of these abiotic factors that controls opportunistic macroalgal growth and biomass in the south arm of the estuary. The present results suggest an exponential increase of green macroalgal biomass with salinity until 30 . The increase of macroalgal biomass with salinity agrees with a previous work (Martins et al., 1999), which tested Enteromorpha intestinalis growth response along salinity gradients. Although E. intestinalis growth increased with salinity, the optimum range was $17-22$ and then growth decreased with the rise of salinity. Nevertheless, E. intestinalis growth was lower at low salinity than at high salinity. This may also explain the low spring growth rates of Enteromorpha spp. (6\% day $^{-1}$ ) obtained in 1996, when salinity was kept quite low (average salinity between January-June $1996=14)$. There is some evidence that green macroalgae accumulate detrimental polyamines (such as putrescine and spermidine) when submitted to hyposaline stress (Lee, 1998), which might explain their lower growth rates.

The occurrence of high N:P ratios in the water column might suggest that primary production is P-limited (Valiela, 1995). In the case of green macroalgae, such as Enteromorpha and Ulva, they can store both $\mathrm{N}$ and P (Fujita, 1985; Björnsäter \& Wheeler, 1990; Poole \& Raven, 1997) and their growth rate is considered to be dependent on internal nutrient concentrations (Björnsäter \& Wheeler, 1990; Bendoricchio et al., 1994; Solidoro et al., 1997), while their uptake rates depend on the difference between internal nutrient concentration in macroalgal cells and external nutrient concentration in the water. Due to these mechanisms, there are time lags between low water column nutrient concentrations and the onset of nutrient-limited growth (Björnsäter \& Wheeler, 1990; Poole \& Raven, 1997), therefore, instantaneous water column concentrations are not suitable for establishing nutrient availability of macroalgae (Fujita, 1985). However, since in the south arm of the estuary, N:P ratios can remain high for significant periods of time (e.g. October-December 1993, throughout 1996) and show a tendency to increase whenever river flow increases, it is possible that there is a potential for phosphorus limitation of primary producers in certain periods of the year.

Increased current velocities enhance the export of free-floating materials from the system to the ocean. In the case of macroalgae, it has been argued that advective transport is a significant mechanism in controlling their biomass, especially of the free-floating species like Ulva sp. (Salomonsen et al., 1999). The transport of free-floating macroalgae (Ulva sp. and Chaetomorpha sp.) was linearly correlated with current velocity (Flindt et al., 1997b) and, apparently significant amounts of macroalgal biomass can be lost due to export mechanisms (Hernández et al., 1997; Flindt et al., pers. comm.). In the case of Enteromorpha, in spite of their ability to fix to substrata on the sediment, it can not completely resist the water-flow. Strong tidal currents erode the attachment of Enteromorpha or tear away their fronds once they reach a critical length (Lowthion et al., 1985). Such evidence was found in Langstone Harbour (U.K.), where maximum current velocity is about $1.22 \mathrm{~m} \mathrm{~s}^{-1}$ (Lowthion et al., 1985). In the south arm of the Mondego Estuary, where current velocity can reach $1.4 \mathrm{~m} \mathrm{~s}^{-1}$, the loss of Enteromorpha biomass by export may thus constitute an important mechanism.

Increased light extinction coefficients caused by high turbidity of the water column contribute to decrease the amount of light available for photosynthesis. Because the south arm of the estuary is a shallow area and most of the flats where macroalgae proliferate are intertidal, light-limitation may not be an issue during low-tide hours, when intertidal flats are immersed. However, the amount of suspended matter in the water column will influence photosynthetic rates during high-tide hours and, as a result, macroalgal growth will certainly be lower whenever water-flow velocity is higher.

The processes described here seem to explain the significant inter-annual variation of macroalgal standing crop in the eutrophic system constituted by the south arm of the Mondego Estuary. Furthermore, the present results show that the annual productivity of Enteromorpha spp. is strongly dependent on the weather conditions and the river management practices during winter and spring. These mechanisms are summarized in Table 1.

This work shows how the onset of opportunistic macroalgal blooms in an estuarine system is dependent on precipitation and on water-management practices in upstream agricultural lands.

The dependency of macroalgal production on hydrodynamics also determines that during periods of 
TABLE 1. Summarized description of the variation of the main factors controlling green macroalgal growth and production during spring in the south arm of the Mondego Estuary. The variation of these factors depends both on precipitation and on river management practices according with the water needs of the upstream rice fields

Dry winter and/or spring

Rainy winter and spring

\begin{tabular}{lcc}
\hline $\begin{array}{l}\text { Sluice gates } \\
\text { (river management) }\end{array}$ & Closed & Opened \\
Salinity & High & Low \\
TIN & Low & High \\
N:P & Near 16 & High \\
Light extinction coefficients & Normal for shallow estuaries & High \\
Water-flow velocity & Low & High \\
Green macroalgal growth & High & Low \\
\end{tabular}

high river-flow, important amounts of nutrients, especially $\mathrm{NO}_{3}-\mathrm{N}$, are rapidly exported to the ocean. When river-flow decreases, nutrients can remain for longer periods in the system and become incorporated in macroalgal tissues, which act as seasonally important nutrient sinks of the ecosystem.

\section{Acknowledgements}

We thank the Portuguese Foundation for Science and Technology (FCT) which supported this work through a Ph.D. grant to I. Martins, and EU projects 'MUST-Marine Universal Structural Model' and 'WET - Wetland Ecology and Technology'.

The authors are indebted to all colleagues that assisted in field and laboratory work and, especially, to P. Maranhão for allowing us to use his salinity data from 1995.

\section{References}

Anastácio, P. M., Frias, A. F. \& Marques, J. C. 1999 CRISP (crayfish and rice integrated system of production): 1. Modelling rice (Oryza sativa) growth and production. Ecological Modelling $123,17-28$

Bendoricchio, G., Coffaro, G. \& De Marchi, C. 1994 A trophic model for Ulva rigida in the Lagoon of Venice. Ecological Modelling 75/76, 485-496.

Björnsäter, B. R. \& Wheeler, P. A. 1990 Effect of nitrogen and phosphorus supply on growth and tissue composition of Ulva fenestrata and Enteromorpha intestinalis (Ulvales, Chlorophyta). Fournal of Phycology 26, 603-611.

Flindt, M. R., Kamp-Nielsen, L., Marques, J. C., Pardal, M. A., Bocci, M., Bendoricchio, G., Salomonsen, J., Nielsen, S. N. \& Jørgensen, S. E. $1997 a$ Description of the three shallow estuaries: Mondego River (Portugal), Roskilde Fjord (Denmark) and the Lagoon of Venice (Italy). Ecological Modelling 102, 17-31.

Flindt, M. R., Salomonsen, J., Carrer, M., Bocci, M. \& Kamp-Nielsen, L. $1997 b$ Loss, growth and transport dynamics of Chaetomorpha aerea and Ulva rigida in the Lagoon of Venice during an early summer field campaign Ecological Modelling 102, 133-141.

Fujita, R. M. 1985 The role of nitrogen status in regulating transient ammonium uptake and nitrogen storage by macroalgae. Fournal of Experimental Marine Biology and Ecology 92, 283-301.
Geertz-Hansen, O., Sand-Jensen, K., Hansen, D. F. \& Christiansen, A. 1993 Growth and grazing control of abundance of the marine macroalga, Ulva lactuca L. in a eutrophic Danish estuary. Aquatic Botany 46, 101-109.

Greenberg, A. E., Clesceri, L. S. \& Eaton, A. D. (eds) 1992 Standard methods for the examination of water and wastewater, 18th edition. APHA, AWWA, WEF.

Herman, P. M. J., Hemminga, M. A., Nienhuis, P. H., Verschuure, J. M. \& Wessel, E. G. J. 1996 Wax and wane of eelgrass Zostera marina and water column silicon levels. Marine Ecolology Progress Series 144, 303-307.

Hernández, I., Peralta, G., Pérez-Lloréns, J. L., Vergara, J. J. \& Niell, F. X. 1997 Biomass and dynamics of growth of Ulva species in Palmones River Estuary. Fournal of Phycology 33, $764-772$.

Koch, E. W. \& Beer, S. 1996 Tides, light and distribution of Zostera marina in Long Island Sound, USA. Aquatic Botany 53, 97-107.

Kolbe, K., Kaminski, E., Michaelis, H., Obert, B. \& Rahmel, J. 1995 Macroalgal mass development in the Wadden Sea: first experiences with a monitoring system. Helgolander Meeresuntersuchungen 49, 519-528.

Lapointe, B. E., Tomasko, D. A. \& Matzie, W. R. 1994 Eutrophication and trophic state classification of seagrass communities in Florida Keys. Bulletin of Marine Science 54, 696-717.

Lillebø, A. I., Pardal, M. A. \& Marques, J. C. 1999 Population structure, dynamics and production of Hydrobia ulvae (Pennant) (Mollusca: prosobranchia) along an eutrophication gradient in the Mondego estuary (Portugal). Acta Oecologica 20, 289-304.

Lee, T.-M. 1998 Investigations of some intertidal green macroalgae to hyposaline stress: Detrimental role of putrescine under extreme hyposaline conditions. Plant Science 138, 1-8.

Lopes, R. J., Pardal, M. A. \& Marques, J. C. 2000 Impact of macroalgae blooms and wader predation on intertidal macroinvertebrates-Experimental evidence in the Mondego estuary (Portugal). Fournal of Experimental Marine Biology and Ecology 249, 165-179.

Lowthion, D., Soulsby, P. G. \& Houston, M. C. M. 1985 Investigation of a eutrophic tidal basin: $1-$ Factors affecting the distribution and biomass of macroalgae. Marine Environmental Research 15, 263-284.

Marques, J. C. \& Nogueira, A. 1991 Life cycle, dynamics, and production of Echinogammarus marinus (Leach (Amphipoda)) in the Mondego estuary (Portugal). Oceanologica Acta 11, 213-223.

Marques, J. C., Rodrigues, L. B. \& Nogueira, A. J. A. 1993 a Intertidal macrobenthic communities structure in the Mondego estuary (Western Portugal): Reference situation. Vie Millieu 43, 177-187.

Marques, J. C., Maranhão, P. \& Pardal, M. A. 19936 Human impact assessment on the subtidal macrobenthic community structure in the Mondego Estuary (Western Portugal). Estuarine, Coastal and Shelf Science 37, 403-419. 
Marques, J. C., Martins, I., Teles-Ferreira, C. \& Cruz, S. 1994 Population dynamics, life history, and production of Cyathura carinata (Krøyer) (Isopoda: Anthuridae) in the Mondego Estuary, Portugal. Fournal of Crustacean Biology 14, 258-272.

Marques, J. C., Pardal, M. A., Nielsen, S. N. \& Jørgensen, S. E. 1997 Analysis of the properties of exergy and biodiversity along an estuarine gradient of eutrophication. Ecological Modelling 102, $155-167$.

Marques, J. C., Pardal, M. A. \& Lillebø, A. I. 1999 Comunidades biológicas do estuário do Mondego: quinze anos de estudos. Cadernos de Ecologia 2, 46-76.

Martins, I., Marques, J. C., Jørgensen, S. E. \& Nielsen, S. N. 1997 Modelling the effects of macroalgae blooms on the population dynamics of Cyathura carinata (Crustacea: Isopoda) in a eutrophied estuary. Ecological Modelling 102, 33-53.

Martins, I., Oliveira, J. M., Flindt, M. R. \& Marques, J. C. 1999 The effect of salinity on the growth rate of the macroalgae Enteromorpha intestinalis (Chlorophyta) in the Mondego estuary (west Portugal). Acta Oecologica 20, 259-265.

Martins, I. I. C. 2000 Green macroalgae and seagrasses in a shallow eutrophic estuary, the Mondego Estuary: Dynamics, controlling factors and possible evolutionary scenarios. Ph.D Thesis, FCT-University of Coimbra.

Masini, R. J., Cary, J. L., Simpson, C. J. \& McComb, A. J. 1995 Effect of light and temperature on the photosynthesis of temperate meadow-forming seagrasses in Western Australia. Aquatic Botany 49, 239-254.

McClelland, J. W. \& Valiela, I. 1998 Changes in food web structure under the influence of increased anthropogenic nitrogen inputs to estuaries. Marine Ecology Progress Series 168, 259-271.

Morand, P. \& Briand, X. 1996 Excessive growth of macroalgae: a symptom of environmental disturbance. Botanica Marina 39, 491-516.

Múrias, T., Cabral, J. A., Marques, J. C. \& Goss-Custard, J. D. 1996 Short-term effects of intertidal macroalgal blooms on the macrohabitat selection and feeding behaviour of wading birds in the Mondego estuary (West Portugal). Estuarine, Coastal and Shelf Science 43, 677-688.

Múrias, T., Cabral, J. A., Lopes, R. \& Marques, J. C. 1997 Low-water use of the Mondego estuary (West Portugal) by waders (Charadrii). Ardeola 44, 79-91.

Neira, C. \& Rackaman, H. 1996 Black spots produced by buried macroalgae in intertidal sandy sediments of the Wadden Sea: effects on the meiobenthos. Fournal of Sea Research 36, 153-170.

Pardal, M. A. C. 1998 Impacto da eutrofização nas comunidades macrobentónicas do braço sul do estuário do Mondego. Ph.D. Thesis, FCT-University of Coimbra.

Pardal, M. A., Marques, J. C., Metelo, I., Lillebø, A. I. \& Flindt, M. R. 2000 Impact of eutrophication on the life cycle, population dynamics and production of Amphithoe valida (Amphipoda) along an estuarine spatial gradient (Mondego estuary, Portugal). Marine Ecology Progress Series 196, 207-219.

Peckol, P. \& Rivers, J. S. 1996 Contribution by macroalgal mats to primary production of a shallow embayment under high and low nitrogen-loading rates. Estuarine, Coastal and Shelf Science 43, 311-325.

Poole, L. J. \& Raven, J. A. 1997 The biology of Enteromorpha. Progress in Phycological Research 12 (F. E. Round/D. J. Chapman, eds), Biopress Ltd, $123 \mathrm{pp}$.

Raffaelli, D., Limia, J., Hull, S. \& Pont, S. 1991 Interactions between the amphipod Corophium volutator and macroalgal mats on estuarine mudflats. Fournal of the Marine Biological Association of the UK 71, 899-908.

Salomonsen, J., Flindt, M., Geertz-Hansen, O. \& Johansen, C. 1999 Modelling advective transport of Ulva lactuca (L.) in the sheltered bay, Møllekrogen, Roskilde Fjord, Denmark. Hydrobiologia 397, 241-252.

Sfriso, A. 1995 Temporal and spatial responses of growth of Ulva rigida C. Ag. To environmental and tissue concentrations of nutrients in the Lagoon of Venice. Botanica Marina 38, 557-573.

Short, F. T., Burdick, D. M. \& Kaldy, III J. E. 1995 Mesocosm experiments quantify the effects of eutrophication on eelgrass, Zostera marina. Limnology and Oceanography 40, 740-749.

Sokal, R. R. \& Rohlf, F. J. 1995 Biometry, 3rd edition. Freeman Press, New York, $887 \mathrm{pp}$

Solidoro, C., Pecenik, G., Pastres, R., Franco, D. \& Dejak, C. 1997 Modelling macroalgae (Ulva rigida) in the Venice Lagoon: model structure identification and first parameters estimation. Ecological Modelling 94, 191-206.

Valiela, I. 1995 Marine Ecological Processes, 2nd edition. Springer, Berlin, $686 \mathrm{pp}$

Valiela, I., McClelland, J., Hauxwell, J., Behr, P. J., Hersh, D. \& Foreman, K. 1997 Macroalgal blooms in shallow estuaries: controls and ecophysiological and ecosystem consequences. Limnology and Oceanography 42, 1105-1118.

Viaroli, P., Pugnetti, A. \& Ferrari, I. 1992 Ulva rigida growth and decomposition processes and related effects on nitrogen and phosphorus cycles in a coastal lagoon (Sacca di Goro, Po River Delta). In Proceedings of the 25th EMBS (Colombo et al., eds) Olsen \& Olsen, pp. 77-84.

Viaroli, P., Naldi, M., Christian, R. R. \& Fumagalli, I. 1993 The role of macroalgae detritus in the nutrient cycles in a shallow-water dystrophic lagoon. Verh Internat Verein Limnol 25, 1048-1051.

Viaroli, P., Bartoli, M., Bondavalli, C., Christian, R. R., Giordani, G. \& Naldi, M. 1996 Macrophyte communities and their impact on benthic fluxes of oxygen, sulphide and nutrients in shallow eutrophic environments. Hydrobiologia 329, 105-119. 